\title{
Assessment of Microbial Community Composition Changes in the Presence of Phytoplankton-Derived Exudates in Two Contrasting Areas from Chilean Patagonia
}

\author{
Valentina Valdés-Castro 1,2,*iD, Humberto E. González ${ }^{3,4}$, Ricardo Giesecke ${ }^{3,4}$, Camila Fernández ${ }^{1,2,3,4,5}$ \\ and Verónica Molina 2,6 (D)
}

\section{check for} updates

Citation: Valdés-Castro, V.; González, H.E.; Giesecke, R.; Fernández, C.; Molina, V. Assessment of Microbial Community Composition Changes in the Presence of PhytoplanktonDerived Exudates in Two Contrasting Areas from Chilean Patagonia. Diversity 2022, 14, 195. https:// doi.org/10.3390/d14030195 Academic Editors: Ipek Kurtboke and Hera Karayanni

Received: 16 December 2021 Accepted: 23 February 2022 Published: 7 March 2022

Publisher's Note: MDPI stays neutral with regard to jurisdictional claims in published maps and institutional affiliations.

Copyright: (C) 2022 by the authors. Licensee MDPI, Basel, Switzerland. This article is an open access article distributed under the terms and conditions of the Creative Commons Attribution (CC BY) license (https:// creativecommons.org/licenses/by/ $4.0 /)$.
1 Center for Oceanographic Research COPAS Sur-Austral, Universidad de Concepción, Concepcion 4070386, Chile; camilafernandez@oceanografia.udec.cl

2 Center for Oceanographic Research COPAS Coastal, Universidad de Concepción, Concepcion 4070386, Chile; veronica.molina@upla.cl

3 Instituto de Ciencias Marinas y Limnológicas, Universidad Austral de Chile, Valdivia 5090000, Chile; hgonzale@uach.cl (H.E.G.); ricardo.giesecke@uach.cl (R.G.)

4 Centro de Investigación Dinámica de Ecosistemas Marinos de Altas Latitudes (IDEAL), Universidad Austral de Chile, Valdivia 5090000, Chile

5 Laboratoire d'Océanographie Microbienne (LOMIC), Observatoire Océanologique, Sorbonne Universités-Centre National de la Recherche Scientifique, F-66650 Banyuls/Mer, France

6 Departamento de Ciencias y Geografía, Facultad de Ciencias Naturales y Exactas and HUB Ambiental UPLA, Universidad de Playa Ancha, Playa Ancha, Valparaíso 2340018, Chile

* Correspondence: vvaldesc@udec.cl

\begin{abstract}
Patagonian fjords and channels in southern Chile are heterogeneous ecosystems characterized by the interaction of estuarine and marine waters influencing physical-chemical conditions and biological assemblages. Besides salinity, microbial communities from estuarine and marine origin are naturally subjected to changing organic matter quality and variable nutrient concentrations. In this study, we tackle the response of the bacterial community from estuarine and marine origins associated with two size classes $(<0.7 \mu \mathrm{m}$ and $<1.6 \mu \mathrm{m})$ to the addition of sterile phytoplankton-derived exudates (PDE) compared to control conditions (no addition). Picoplanktonic cell abundance, active bacterial composition analyzed through $16 \mathrm{~S}$ rRNA sequencing, changes in dissolved organic carbon (DOC) and $\delta^{13} \mathrm{C}$ were determined over 5 and 15 days after PDE addition. Our results showed that the active marine bacteria were richer and more diverse than their estuarine counterparts, and were dominated by Alphaproteobacteria and Gammaproteobacteria, respectively. PDE addition in both the fractions and the sample origin resulted in an enrichment throughout the incubation of Rhodobacteracea and Cryimorphaceae families, whereas Epsilonproteobacteria (Arcobacteraceae) were mainly favored in the estuarine experiments. Picoplankton abundance increased with time, but higher cell numbers were found in PDE treatments in both size classes $\left(>2 \times 10^{5}\right.$ cell $\left.\mathrm{mL}^{-1}\right)$. In all the experiments, DOC concentration decreased after eight days of incubation, but shifts in $\delta^{13} \mathrm{C}$ organic matter composition were greater in the estuarine experiments. Overall, our results indicate that despite their different origins (estuarine versus marine), microbial communities inhabiting the fjord responded to PDE with a faster effect on marine active bacteria.
\end{abstract}

Keywords: phytoplankton; microbial community composition; organic matter; Patagonian fjords

\section{Introduction}

The ecosystem englobing Patagonian fjords is one of the world's largest estuarine environments, which supports high biological production and vertical carbon export fluxes [1-4]. The hydrographic structure of the fjords and channels of Patagonia is characterized by the presence of subantarctic water (SAAW) with high levels of nitrate and phosphate from the adjacent Pacific Ocean, and freshwater with high levels of silicic acid 
of terrestrial origin $[5,6]$. The surface freshwater layer that is formed by river discharges, precipitation, and glacier melting gradually mixes with the deeper and salty SAAW through estuarine circulation. The influx of freshwater transports important loads of terrestrial organic and inorganic matter to the adjacent coastal areas [7,8]. Consequently, an exacerbated spatial and temporal variability in particulate and dissolved organic matter (POM and DOM) is an inherent characteristic of the fjords and channels of Chilean Patagonia [1-3]. This area is also characterized by high primary production due to the occurrence of phytoplankton blooms during spring [4,9]. All these characteristics influence autotrophic and heterotrophic microbial activity, while shaping the structure of the pelagic community [10].

In this dynamic and complex system, spatial and seasonal variability in microbial community composition have been linked to meltwater discharge associated to shifts in salinity, and macro and micronutrient availability [11-14]. Significant DOM release during phytoplankton blooms has also been associated with important changes in microbial diversity and metabolism, such as those observed in the Puyuhuapi Fjords [15]. Most of the DOM produced during phytoplankton blooms is first channeled through the microbial loop, where part of the DOM is assimilated to building up heterotrophic biomass, which is further transferred to higher trophic levels via predation, mobilizing a significant amount of carbon and energy that otherwise is not available at higher trophic levels [16]. Consequently, the interplay between microbial consumers and DOM release by primary consumers via extracellular release, cell breakdown (predation) or viral lysis is a key component of marine carbon cycling. The release of this DOM, which is usually considered highly labile and can be easily degraded by the heterotrophic bacterial community, can also enhance the remineralization of semi-labile and recalcitrant organic matter through the "priming effect" [17-20]. This process is especially relevant in estuarine systems, where pulses of labile organic matter derived from phytoplankton blooms might enhance landderived carbon degradation, enabling the addition of new carbon sources to estuarine ecosystems [21].

It is known that the addition of labile DOM led to a higher relative abundance and a higher bacterial diversity of several bacterial groups, in particular Alphaproteobacteria, Bacteroidetes, and Verrucomicrobia (e.g., [22]). Under experimental conditions, Bacteroidetes and Alphaproteobacteria can respond under different DOMs derived from phytoplankton, responding to diatom cell lysis and cyanobacteria exudates, respectively [23]. Moreover, in areas where the priming effect is expected, such as river plumes, bacterial community composition did not change [24]. In this sense, most of the knowledge on priming effects comes from studies in soil; the mechanisms controlling the pool of recalcitrant DOM in oceans and, particularly, in fjords are less understood [25].

Herein, we study the differential responses of estuarine and marine bacterial communities to the introduction of fresh DOM derived from phytoplankton and hypothesize that the expected "priming effect" could favor the activity of specific heterotrophic bacteria inhabiting estuarine areas usually exposed to more recalcitrant organic matter. Using an experimental approach, we evaluated changes in the abundance, composition, and diversity of bacterioplankton communities as a response to phytoplankton-derived exudates (PDE; labile DOM).

\section{Materials and Methods}

\subsection{Environmental Conditions}

The study area is located in the Kruger Channel (station 5, $47.89^{\circ} \mathrm{S}-74.56^{\circ} \mathrm{W}$ ) and in the middle of Martinez Channel near the mouth of the Steffen fjord (station 14, $47.81^{\circ} \mathrm{S}$ $74.75^{\circ} \mathrm{W}$; Figure 1) in Chilean Patagonia. This sampling area is under the influence of freshwater discharge from the two largest rivers in Chile (Baker and Pascua rivers). Sampling was conducted during the austral spring of 2014 (October) under the framework of CIMAR20-FIORDOS expedition. Two contrasting stations were selected, station 5 (marine influence) and station 14 (estuarine influence). Experiments were carried out on October 4th and 14th. Water column temperature and salinity were obtained using a CTD 
(Seabird Electronics SBE Model 25, Bellevue, WA, USA). Discrete water samples were collected using Niskin bottles $(2.7 \mathrm{~L})$ arranged on a CTD rosette at standard depths $(0,5$, and $25 \mathrm{~m}$ ). At each depth, subsamples were collected in duplicate for the determination of macronutrients (silicic acid, nitrate and orthophosphate) and chlorophyll-a. Nutrient samples $(11 \mathrm{~mL})$ were filtered through $0.7 \mu \mathrm{m}$ filters (GF/F; Whatman, Maidstone, UK), placed in $11 \mathrm{~mL}$ HDPE plastic tubes (acid washed), and stored at $-20{ }^{\circ} \mathrm{C}$ prior to laboratory analysis. Nutrients were determined using standard colorimetric techniques [26]. These analyses were performed using a Seal analytical AutoAnalyzer AA3 segmented flow at Biochemistry laboratory at Universidad de Concepción, Chile. Chlorophyll-a was measured in duplicate with the fluorometric technique by filtering $200 \mathrm{~mL}$ of seawater through $0.7 \mu \mathrm{m}$ GF/F filters (Parson et al., 1984).

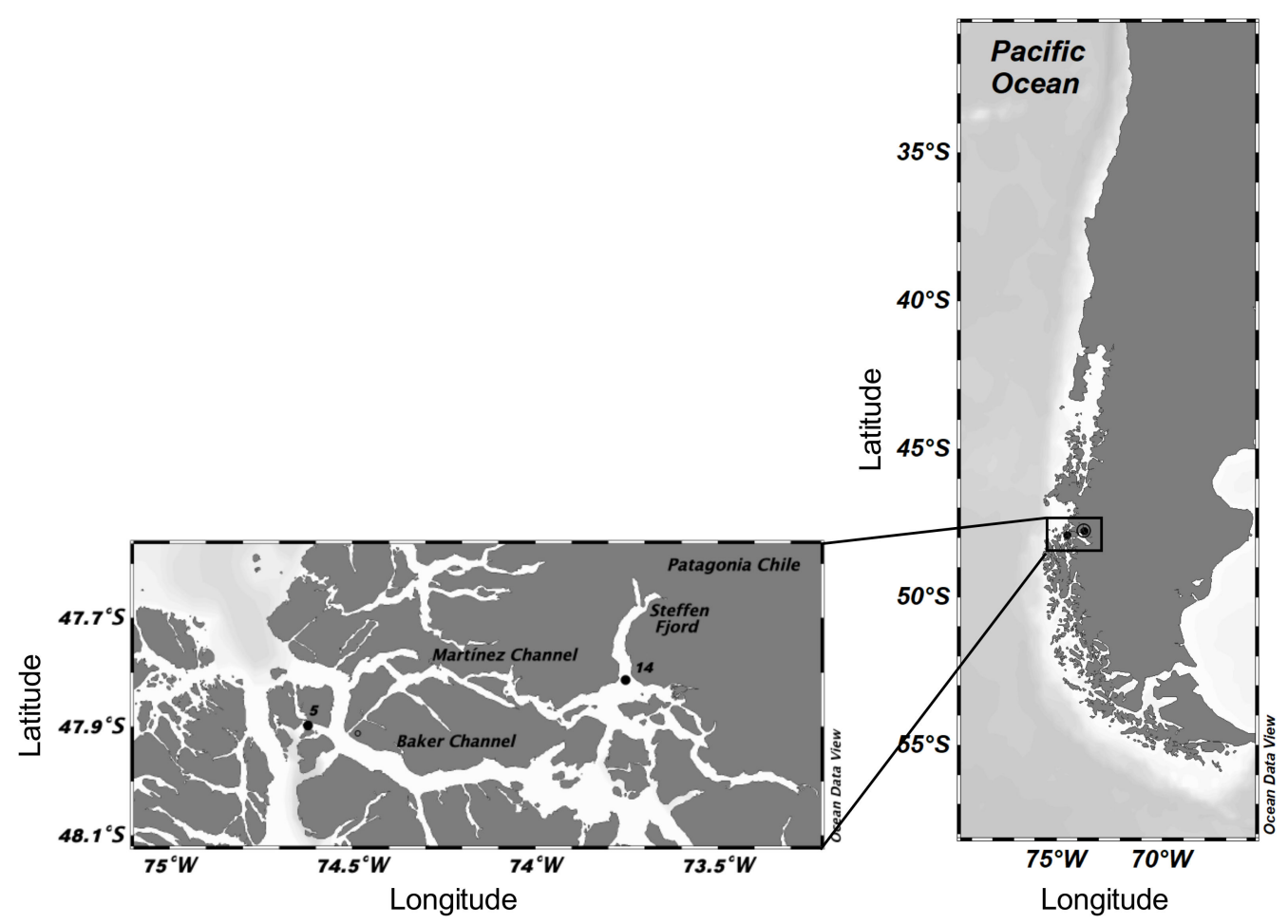

Figure 1. Map showing the location of the stations sampled (dots) in October 2014 in northern Chilean Patagonia.

\subsection{Experimental Design}

To study the response of natural marine and estuarine microbial assemblages to phytoplankton-derived exudates (PDE), surface water $(\sim 12 \mathrm{~L})$ from a $2 \mathrm{~m}$ depth was collected at each station for controls and PDE treatments and the two size fractions were studied. A total of 24 bottles per experiment were used (500 mL, Duran Schott sterile bottles). The experimental incubations consisted of two size fractions to favor microbial communities and avoid grazers; the first was $1.6 \mu \mathrm{m}$ filtered water (APFA04700, Millipore, Burlington, MA, USA), and the second consisted of $0.7 \mu \mathrm{m}$ filtered water (GF/F, Whatman). The natural bacterial community within the 0.7 and $1.6 \mu \mathrm{m}$ size class, hereafter named as "controls", was collected at each station. The DOM experiments consisted of six glass bottles per size fraction that were enriched with $0.5 \mathrm{mg} \mathrm{L}^{-1}$ of DOC from phytoplanktonderived exudates. The DOM stock solution was obtained from phytoplankton exudates derived from cultures of Chaetoceros spp. and Thalassiosira spp., two dominant species in southern Chile, at approximately $4 \times 10^{6}$ cells $/ \mathrm{mL}$ densities. Cultures of Chaetoceros spp. and Thalasisiosira spp. were obtained from FICOLAB laboratory at the University of Concepción. A liquid cell suspension from cultures was gently filtered through $0.2 \mu \mathrm{m}$, avoiding potential contamination of the samples. 
All the bottles were incubated in the dark and in situ simulated temperature conditions using an onboard marine water recirculation system. The recirculation system consisted of two large incubators connected by hoses, through which surface seawater from each station circulated. Subsamples were collected for DOC, $\delta^{13} \mathrm{C}$, picoplankton abundance and nanoplankton abundance, and to determine the active bacterial composition at intervals of 0 (initial condition), 3, 5, 8, 12, and 15 days after incubation. Furthermore, nitrate $\left(\mathrm{NO}_{3}{ }^{-}\right)$, silicic acid $\left(\mathrm{Si}(\mathrm{OH})_{4}\right)$ and orthophosphate $\left(\mathrm{PO}_{4}{ }^{3-}\right)$ were determined at sampling intervals of 0,5 , and 15 days using the same analytic procedures as described before. Inorganic nutrient results are available as Supplementary Materials.

A sample of $500 \mathrm{~mL}$ was filtered through a combusted $0.7 \mu \mathrm{m}$ GF/F filter for particulate organic carbon analysis. The carbon $\left(\delta^{13} \mathrm{C}\right)$ isotope was analyzed by mass spectrometry using a Thermo Scientific Delta V Advantage IRMS with EA-2000 Flash Elemental analyzer at the Laboratory of Biogeochemistry and Applied Stable Isotopes (Pontificia Universidad Católica, Santiago, Chile). The $\delta^{13} \mathrm{C}(\%)$ standard used was Pee Dee Belemnite (PDB). For DOC determinations, a subsample of $40 \mathrm{~mL}$ was filtered through a $0.22 \mu \mathrm{m}$ sterile syringe MilliporeMillex ${ }^{\circledR}$ (Merck Millipore, Burlington, MA, USA), stored in $40 \mathrm{~mL}$ amber I-Chem 200 vials (Thermo Scientific Certified ${ }^{\mathrm{TM}}$, Waltham, MA, USA), and acidified with $300 \mu \mathrm{L}$ trace metal grade $\mathrm{HCl}$. DOC was analyzed using the high-temperature catalytic oxidation (HTCO) technique [27] using a Shimadzu TOC-5000 carbon analyzer. Picoplankton abundance was analyzed by flow cytometry [28] with a FACSCalibur flow cytometer (Becton Dickinson, Franklin Lakes, NJ, USA), and nanoplankton abundance was analyzed by epifluorescence microscopy [29].

\subsection{Active Bacteria, Nucleic Acid Extraction, and Sequencing Procedure}

The bacterial community at each time interval was concentrated from a $100 \mathrm{~mL}$ water sample onto $0.22 \mu \mathrm{m}$ hydrophilic PVDF filters (Millipore) using a sterilized syringe and a $25 \mathrm{~mm}$ filter holder (Merck Millipore, Burlington, MA, USA). The filters were preserved in $1.5 \mathrm{~mL}$ cryovials with RNAlater solution (Ambion, Austin, TX, USA), frozen in liquid nitrogen in the field and stored at $-80{ }^{\circ} \mathrm{C}$ prior to RNA extraction in the laboratory. RNA samples were taken in duplicate and were extracted using a Mirvana kit (AM1560; Ambion, Austin, TX, USA), as described previously by Valdés et al. [30]. RNA extracts were then treated to remove DNA tracer with a TURBO DNA-free kitTM (Ambion) and quantified using a Qubit fluorometer (Thermo Fisher Scientific), following the manufacturer's instructions. The RNA was reverse-transcribed to cDNA using random primers with the ImProm-II Reverse Transcription System (Promega, Madison, WI, USA). Amplification was checked using standard PCR to amplify the V1-V3 region of bacterial 16S rRNA (27F-519R). The cDNA templates were sequenced using the Illumina high-throughput sequencing method at the Research and Testing Laboratory (RTL, Lubbock, TX, USA).

\section{4. $16 S$ rRNA Gene Sequence Analyses and Microbial Community Characterization}

The 16S rRNA gene sequence analyses were performed using Mothur software v1.35.1 [31]. Sequencing data sets were curated by quality filtration to minimize the effects of random sequencing errors by eliminating short sequence reads $<200 \mathrm{bp}$, sequences that contained more than one undetermined nucleotide, and sequences with a maximum homopolymer length of eight nucleotides. Thereafter, chimeric sequences were identified using the chimera UCHIME algorithm and removed [32]. The curated 16S rRNA gene sequences were taxonomically classified using automatic software pipeline SILVAngs available from https:/ / www.arb-silva.de/ (accessed on 14 December 2021) [33]. At the marine station, a total of 143,842 gene sequences were analyzed, ranging between 7861 and 21,752 sequences for each library. At the estuarine station, 127,158 sequences were analyzed from 4384 and 11,212 for each library. Libraries were deposited in the European Nucleotide Archive (ENA) under study accession PRJEB42326 with the following run access numbers: ERS5801012-ERS5801039. 
The composition was identified at phyla, class, order, and family for taxonomic levels as abundant $(>0.5 \%)$ and others $(<0.5 \%)$ in total sequences retrieved from each library. Since the number of sequences per sample was variable, we previously rarefied the different library sizes using a subsampling routine in Mothur software [31] to reflect the lowest number of sequences encountered (station 5: 7861 and station 14: 4384).

\subsection{Statistical Analysis}

Statistical analysis of the effect of the different treatments (PDE addition, incubation time and different sizes of bacterial assemblages) on DOC, $\delta^{13} \mathrm{C}$, picoplankton abundance, and Shannon index, were performed using a 3-way analysis of variance (ANOVA) after checking for normality assumptions (Kolmogorov-Smirnov test) and homoscedasticity (Levene's test). A pairwise multiple comparison was performed using a Tukey test as a posteriori analysis.

Bacterial community structures were compared using ordination Bray-Curtis similarities, visualized in Unweighted Pair Group Method with Arithmetic mean (UPGMA) dendrograms, whose nodes were further tested using a bootstrap analysis. A multivariate analysis was also used to analyze the variability of biological and environmental variables, using PRIMER v.6 and the add-on PERMANOVA+ software package. The permutational multivariate analysis of variance (PERMANOVA) with a fixed factor was used to investigate the differences in bacterial community composition for treatments with PDE addition and control, treatment with different bacterioplankton sizes, and between the different incubation times, in both experiments. Principal coordinate analysis ( $\mathrm{PCoA}$ ) was performed to visualize the patterns of the operational taxonomic units (OTUs) of the bacterial community in response to different treatments.

\section{Results}

\subsection{Hydrographic and Biogeochemical Conditions}

The surface layer was generally characterized by low temperature, $8-9.5{ }^{\circ} \mathrm{C}$, and variable salinity considering the east-to-west transect sampled (Figure 2A,B). Marine station presented the lowest temperature $\left(\sim 8{ }^{\circ} \mathrm{C}\right)$ at the surface up to $15 \mathrm{~m}$ depth with a weak thermocline, while the estuarine station presented a subsurface minimum between 5 and $10 \mathrm{~m}$, causing a thermal inversion from station 14 to station 5 , as a result of the freshwater inflow towards the west (Figure 2A). As expected, salinity controls the vertical structure along the east to west transect, with lower salinities close to the outlet of Steffen fjord with a marketed halocline at $8 \mathrm{~m}$ at station 14 (7.5 and $22 \mathrm{PSU})$, followed by a gradual increase in salinity towards station 5 (32 PSU). The estuarine waters associated with the Steffen fjord were characterized by lower nitrate and phosphate (below 7.5 and $0.5 \mu \mathrm{mol} \mathrm{L}^{-1}$, respectively; Figure 2C-E) and higher silicate concentrations $\left(15-25 \mu \mathrm{mol} \mathrm{L}^{-1}\right)$ compared with the Kruger channel. At this site and below the pycnocline, the phosphate and nitrate concentrations were higher (15-26 and 1-2.5 $\mathrm{mol} \mathrm{L}^{-1}$, respectively), while the silicate concentrations remained $<7.5 \mu \mathrm{mol} \mathrm{L}^{-1}$ compared to the Steffen fjord station (Figure 2). 


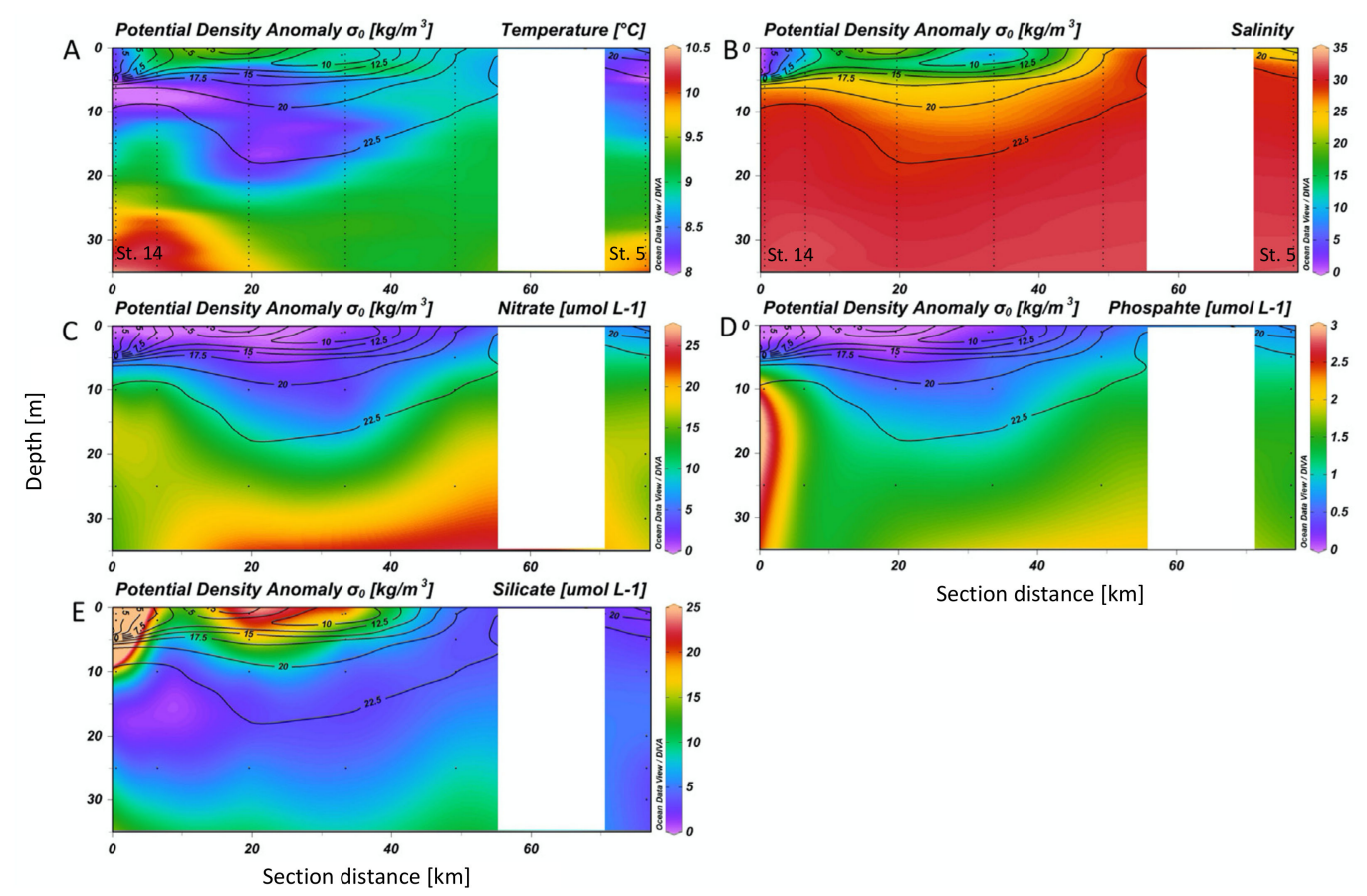

Figure 2. (A) temperature $\left({ }^{\circ} \mathrm{C}\right),(\mathbf{B})$ salinity (PSU), (C) nitrate $\left(\mu \mathrm{mol} \mathrm{L}^{-1}\right),(\mathbf{D})$ phosphate $\left(\mu \mathrm{mol} \mathrm{L}{ }^{-1}\right)$, and (E) silicate $\left(\mu \mathrm{mol} \mathrm{L}{ }^{-1}\right)$ spatial variability in an east-(Kruger channel)-to-west (Steffen fjord) transect. Surface water for the experiments was obtained from the marine-influenced station 5 and the estuarine station 14 .

The chlorophyll-a (Chl-a) concentrations showed higher concentrations at surface at a $0 \mathrm{~m}$ depth for total Chl-a and $<20 \mu \mathrm{m}$, but for both $<20 \mu \mathrm{m}$ and 2-20 $\mu \mathrm{m}$ sizes, the maxima occurred at $5 \mathrm{~m}$ at the marine station 5 (Table 1 ). At the estuarine station 14, higher values of chlorophyll-a were observed at subsurface depth $(5 \mathrm{~m})$ for total and almost all fractions, except for the 2-20 $\mu \mathrm{m}$ size fraction, where the highest concentration was observed at $10 \mathrm{~m}$ depth.

Table 1. Fractionated chlorophyll-a concentrations $\left(\mathrm{mg} \mathrm{m}^{-3}\right)$ in marine station 5 and estuarine station 14.

\begin{tabular}{|c|c|c|c|c|c|}
\hline \multirow{2}{*}{ Station } & \multirow{2}{*}{ Depth (m) } & \multicolumn{4}{|c|}{ Chlorophyll-a (mg m$\left.{ }^{-3}\right)$} \\
\hline & & Total & $<2 \mu \mathrm{m}$ & $2-20 \mu \mathrm{m}$ & $>20 \mu \mathrm{m}$ \\
\hline \multirow[t]{5}{*}{5} & 0 & $8.38 \pm 9.34$ & $0.74 \pm 0.00$ & $1.64 \pm 0.00$ & $5.99 \pm 9.34$ \\
\hline & 5 & $4.26 \pm 0.91$ & $0.93 \pm 0.01$ & $2.57 \pm 1.26$ & $0.76 \pm 2.18$ \\
\hline & 10 & $3.06 \pm 0.17$ & $0.28 \pm 0.03$ & $0.74 \pm 0.03$ & $2.03 \pm 0.16$ \\
\hline & 25 & $0.98 \pm 0.03$ & $0.08 \pm 0.01$ & $0.30 \pm 0.11$ & $0.60 \pm 0.15$ \\
\hline & 50 & $0.10 \pm 0.02$ & $0.24 \pm 0.00$ & $1.38 \pm 0.00$ & $0.00 \pm 0.00$ \\
\hline \multirow[t]{5}{*}{14} & 0 & 1.40 & 0.18 & 1.02 & 0.20 \\
\hline & 5 & 10.77 & 0.61 & 1.83 & 8.33 \\
\hline & 10 & 2.61 & 0.37 & 2.39 & 0 \\
\hline & 25 & 0.11 & 0.12 & 1.11 & 0 \\
\hline & 50 & 0.19 & 0.06 & 0.62 & 0 \\
\hline
\end{tabular}

3.2. Changes in Biogeochemical Conditions after PDE Addition to the Different Picoplanktonic Fractions

The PDE enrichment and control experiments resulted in DOC changes over time. At the marine station, DOC concentration was significantly higher in the treatment with the PDE addition compared to the controls (Figure 3B; ANOVA; $p<0.0001$ ) but no significant differences were observed between size classes (ANOVA; $p=0.7$ ). Furthermore, 
slight differences were observed between times, highlighting a slight increase at 5 days of incubation in the controls compared to the initial time (ANOVA and Tukey's test; $p<0.05$ ). At the estuarine station (Figure 3D), the DOC concentration was significantly higher with PDE addition (ANOVA, $p<0.0001$ ), but no significant differences were found between the different size classes of natural bacterial assemblages or between incubation times (ANOVA, $p=0.22$ and $p=0.08$, respectively).
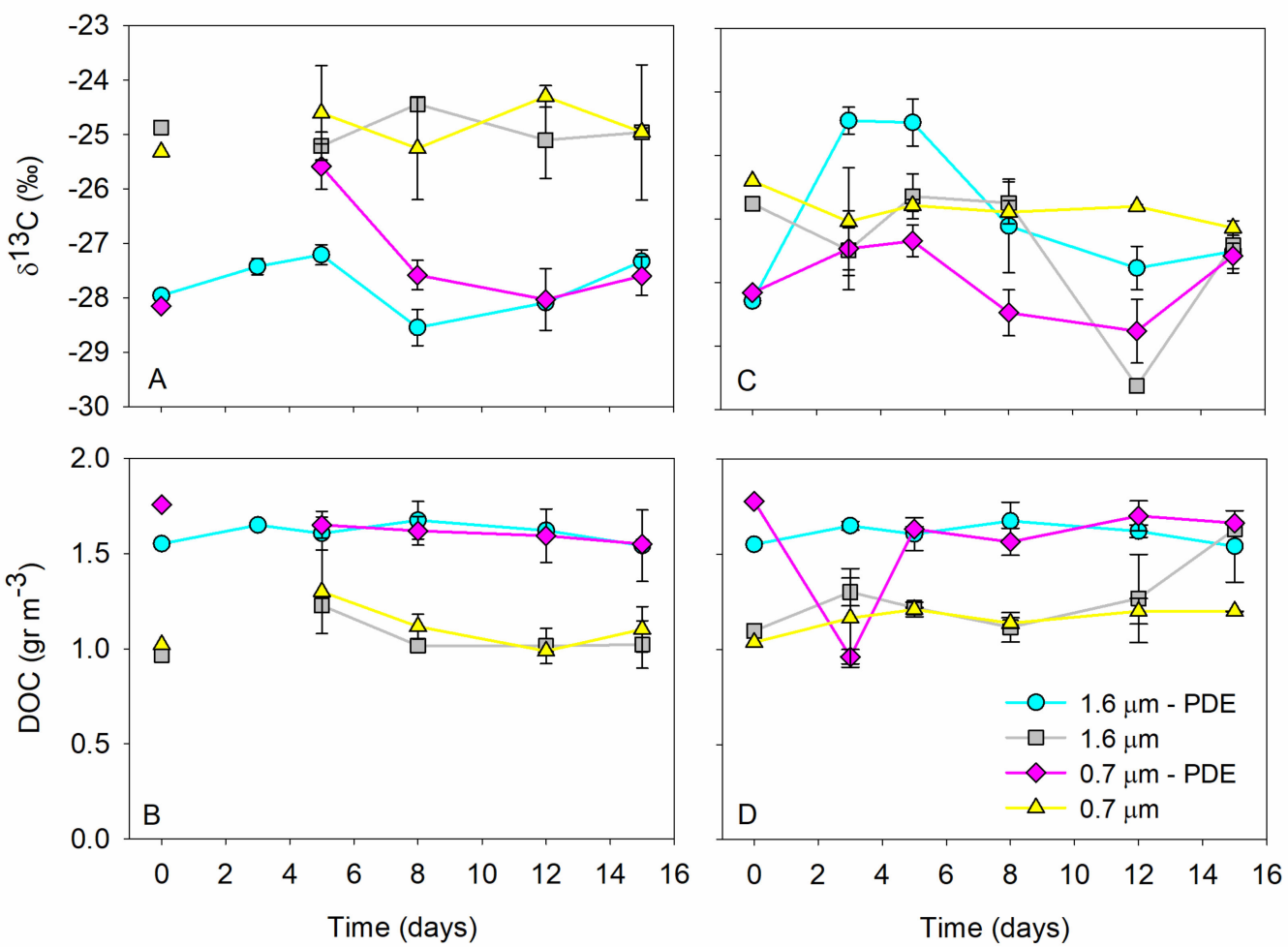

Figure 3. $\delta^{13} \mathrm{C}(\%)(\mathbf{A}, \mathbf{C})$ and DOC concentration $\left(\mathrm{gr} \mathrm{m}^{-3}\right)(\mathbf{B}, \mathbf{D})$ from the different treatments, with PDE addition and control, and for the different bacterioplankton. Left panel corresponds to marine station 5 and the right panel to estuarine station 14 .

Along the course of the experiment, significant differences were observed in $\delta^{13} \mathrm{C}$ between the treatments with PDE addition and controls at the marine station (ANOVA; $p<0.0001$ ) and the estuarine station (ANOVA; $p=0.015$; Figure 3A,C). At marine station 5, the higher enrichment values were found in the controls $(-25 \%$ in average) and the lowest values were found in the treatments with PDE addition ( $-28 \%$ in average). A significant enrichment was observed in the first 5 days of incubation in the treatments with PDE addition compared to the controls, followed by a decrease after 8 and 12 days in the treatment with $1.6 \mu \mathrm{m}$ and $0.7 \mu \mathrm{m}$ size fraction classes, respectively (ANOVA and Tukey's test; $p<0.05)$. However, non-significant differences were found between the different size classes of bacterial assemblages (ANOVA, $p=0.17$ ) at station 5. At station 14, no significant differences were observed between the times (ANOVA, $p=0.06$ ) or between the different cell size classes (ANOVA, $p=0.4$ ).

\subsection{Changes in Picoplankton Abundance during the Incubations}

The changes in picoplankton abundance are shown in Figure 4. During the experiment at the marine station (Figure $4 \mathrm{~A}$ ), the picoplankton abundances were statistically different between the treatment with PDE addition and the control (ANOVA, $p<0.0001$ ). Similarly, the initial picoplankton abundances were statistically higher than between days 5 and 8 (ANOVA and Tukey's test; $p<0.05$ ). By contrast, no significant differences were observed between the different size classes of picoplankton assemblages (ANOVA, $p=0.202$ ). However, the interaction of the factors (PDE additions per size classes of bacteria and per 
time) showed significant effects (ANOVA, $p<0.0001$ ). The picoplankton abundances at the Steffen fjord station showed significant differences between the different picoplankton size classes $(0.7 \mu \mathrm{m}$ and $1.6 \mu \mathrm{m}$; ANOVA, $p=0.01)$. In general, the treatment inoculated with the larger community $(1.6 \mu \mathrm{m})$ showed higher abundances than the lowest size class $(0.7 \mu \mathrm{m})$. The treatment inoculated with the smallest picoplankton community $(0.7 \mu \mathrm{m})$ increased their abundance from the first and third day of incubation in the treatment with PDE addition and the control, respectively. In particular, this increment was abrupt for the treatment with PDE additions at day 3 (Figure 4B). Meanwhile, the treatment inoculated with the largest picoplankton decreased after the first day of incubation. However, no significant difference was observed between the treatments with PDE addition and the controls (ANOVA, $p=0.45$ ), nor between the different times of incubation (ANOVA, $p=0.48$ ), but the interactions between the factors showed significant effects (ANOVA, $p=0.002$ ).

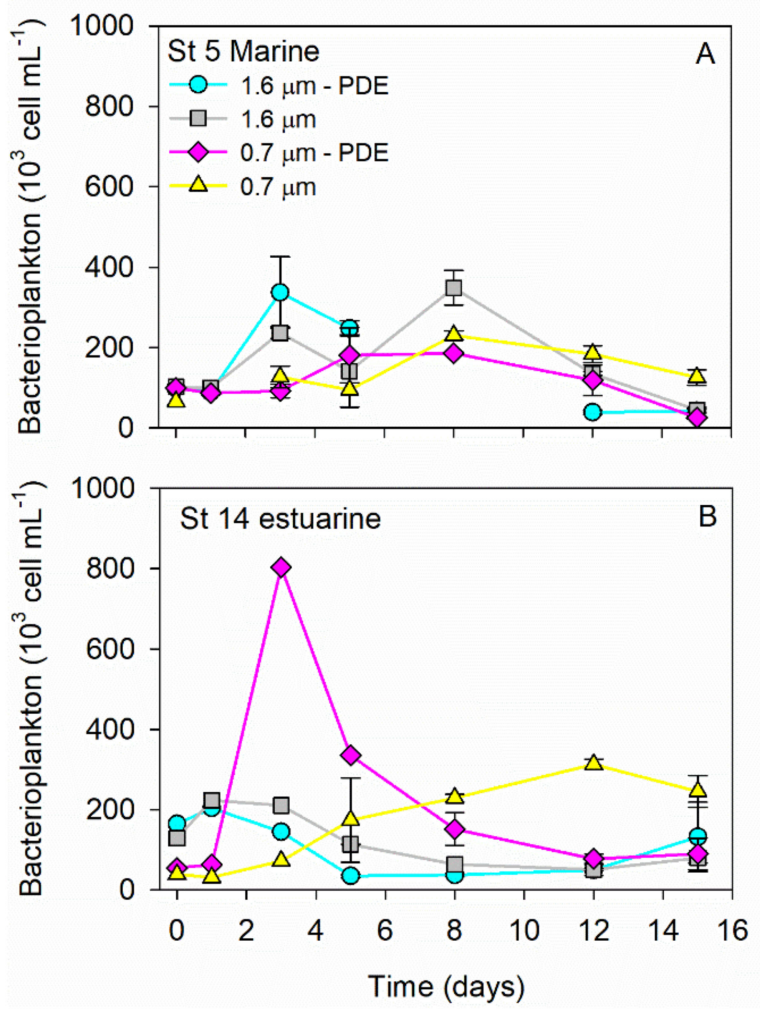

Figure 4. Non-fluorescent picoplankton abundance $\left(10^{3}\right.$ cell $\left.\mathrm{mL}^{-1}\right)$ from the different treatments, with PDE addition and controls, and for the different size fraction of natural bacterial assemblages $(0.7 \mu \mathrm{m}$ and $1.6 \mu \mathrm{m})$. The upper panel corresponds to marine station 5 (A) and the lower panel to estuarine station $14(\mathbf{B})$.

\subsection{Active Bacterial Community Structure and Composition Response to PDE Addition}

The alpha diversity derived from the normalized 16S rRNA libraries (similar sequence numbers) for comparison is shown in Figure 5A,B (station 5) and Figure 5C,D (station 14). At marine station 5, the bacterial taxonomic richness determined (OTU number) and expected on the chao1 index was higher at the initial times in the controls (without PDE addition) in both bacterial size fractions (Figure 5A,B). After PDE addition, the determined and expected richness decreased in the treatment incubated with the smaller picoplankton size class (Figure 5A) and increased in the treatment inoculated with the larger size fraction (Figure 5B). In accordance with this, the Shannon diversity was statistically higher at the initial time in the control in both bacterial size fractions. Furthermore, the Shannon index was statistically different between the controls and PDE additions (ANOVA, $p=0.008$ ), between the different picoplankton size classes (ANOVA, $p=0.02$ ), and between the incubation times (ANOVA, $p=0.005)$. At the estuarine station (station 14), the treatment 
incubated with the smaller bacterial size fraction showed a decrease in the expected and determined richness in the controls, as well for the treatment with PDE addition (Figure 5C), by contrast, the Evenness index increased throughout the incubation. Slight differences were observed in the determined and expected richness in the treatment incubated with the larger size fraction $(1.6 \mu \mathrm{m})$, as well as in the Shannon and Evenness indexes in the treatment with PDE addition and the control. Accordingly, non-significant differences were observed in the Shannon index between PDE addition and the control (ANOVA, $p=0.62$ ), either in the different sizes of picoplankton community (ANOVA, $p=0.26$ ) or between the times (ANOVA, $p=0.47$ ).

(A) Station 5

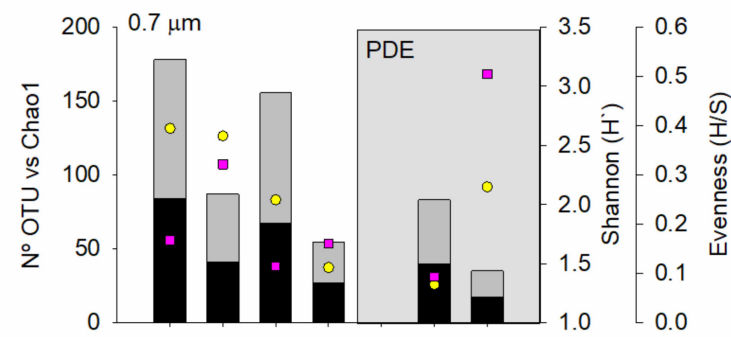

(B)

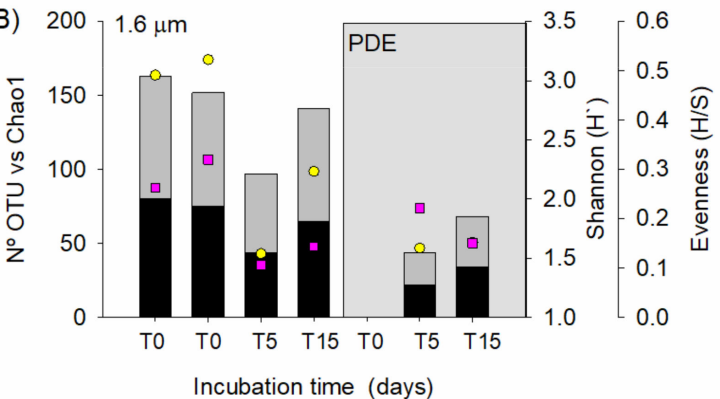

(C) Station 14
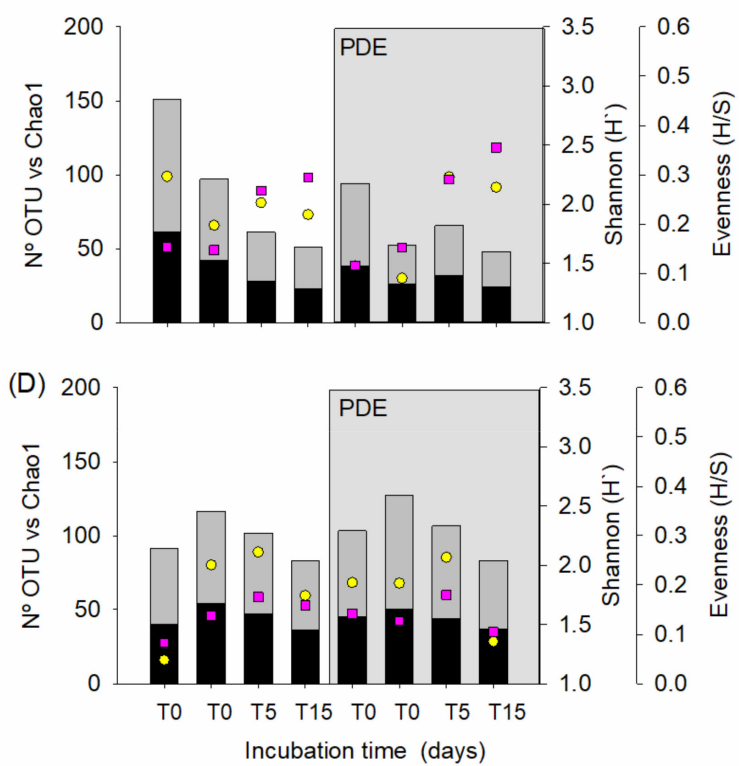

Figure 5. Richness, chao1, diversity (Shannon), and evenness in the bacterial community and over the time course of the experiment for the different treatments, with PDE addition and controls, and for the different bacterial size fractions, $0.7 \mu \mathrm{m}(\mathbf{A}, \mathbf{C})$ and $1.6 \mu \mathrm{m}(\mathbf{B}, \mathbf{D})$. (Left panel) corresponds to marine station and (Right panel) to estuarine station.

At marine station 5, the initial bacterial community composition (control T0; Figure 6) for the treatment incubated with the lower size fraction $(0.7 \mu \mathrm{m})$ was characterized by a higher contribution of Alphaproteobacteria, mainly SAR11 (43\% average between replicates) and Gammaproteobacteria (33\% in average of libraries), mainly SAR86 clade. Similarly, the treatment incubated with the $1.6 \mu \mathrm{m}$ picoplankton size class was characterized by a higher contribution by Alphaproteobacteria (mainly SAR11 and Rhodobacterales), reaching $45 \%$ of the libraries, and Gammaproteobacteria (SAR86 clade), with 29\% (on average). At estuarine station 14, close to Steffen fjord, the initial communities (control) of the treatment incubated with the $0.7 \mu \mathrm{m}$ size class was characterized by a higher contribution of Gammaproteobacteria (45\% average between replicates), mainly Betaproteobacterales, SAR86 clade, and Oceanospirillales, followed by Alphaproteobacteria (42\% average), mainly SAR11 clade. The PDE addition treatments were characterized by Epsilonbacteraeota and Bacteroidetes (mainly Flavobacteria). 

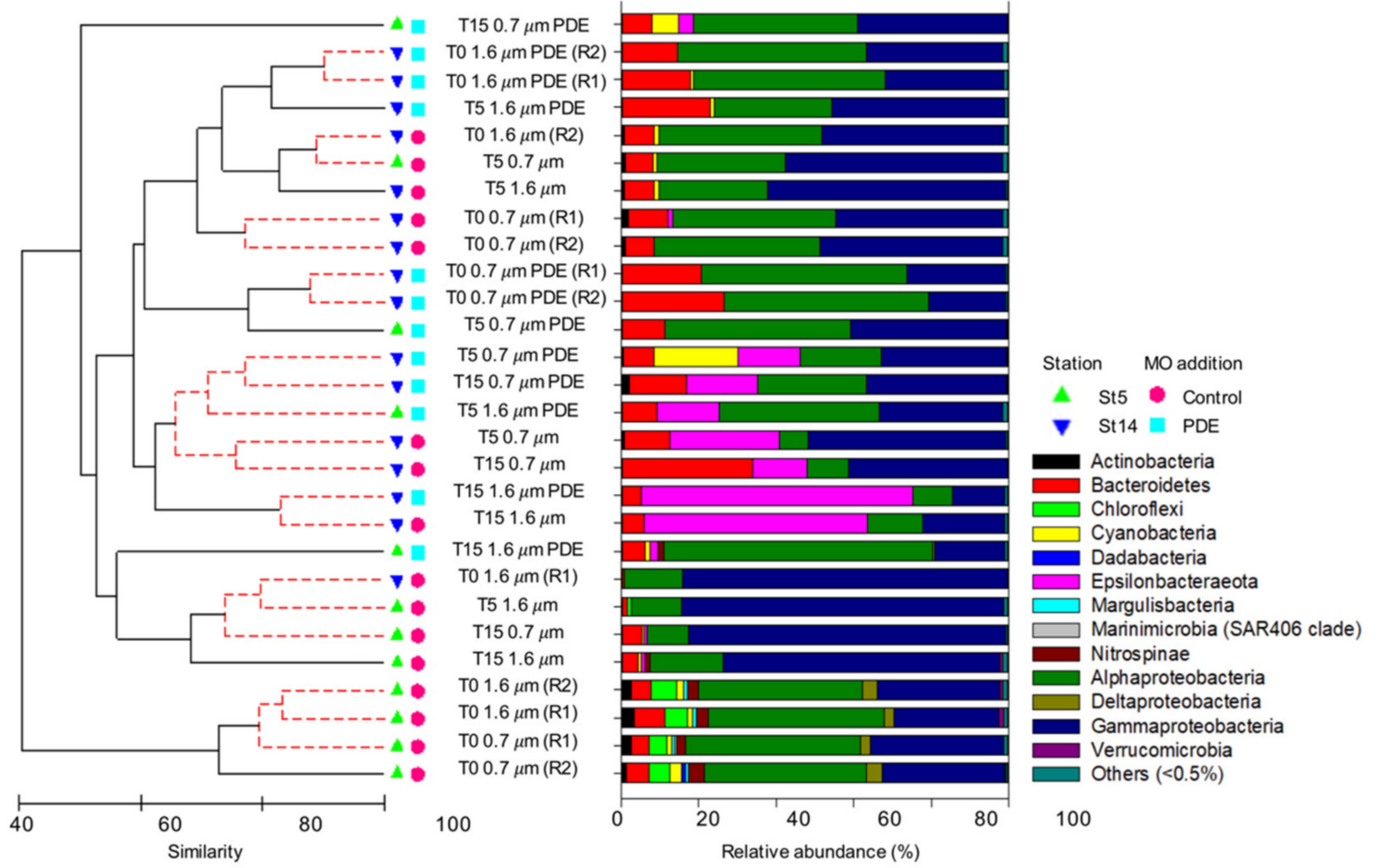

Figure 6. Similarity dendrograms based on the $16 \mathrm{~S}$ rRNA and relative contribution of the abundant bacteria phyla and Proteobacteria subclasses for both stations and all treatments and incubation times. Clustering was on the basis of a distance matrix computed using the Bray-Curtis index of similarity. The dendrogram was inferred with the unweighted pair-group average algorithm (UPGMA). Bacterial communities in the samples connected with red branch lines are not significantly different (SIMPROF test, $p<0.05)$.

A clustering analysis using bacterial orders showed that the variability was mainly associated with the PDE additions and incubation times (Figure 6). In general, the SIMPER analysis indicated that 37 families accounted for $50 \%$ of the dissimilarities between the enrichment treatment (PDE additions) and the controls, and between the different picoplankton sizes (Figure 7). At the marine station (Figure 7), the large picoplankton size class $(1.6 \mu \mathrm{m})$ treatment presented an enrichment of Saccarospirillaceae, from $0.9 \%$ to $34 \%$, from day 5 until the end of the incubation (day 15). A similar enrichment was observed for Colwelliaceae (from 0.4 to 16\%) and Nitrincolaceae (from 0.03 to $14 \%$; specially in the incubation day 5). By contrast, families such as Thioglobacea, SAR86 clade, Burkholderiaceae, and SAR202 clade, among others, reduced their contribution. After PDE addition, Rhodobacteraceae increased its contribution from 11.5 to $50.8 \%$ at the end of incubation, followed by Arcobacteraceae (from 0.4 to $14 \%$ ), Marinobacteraceae (from 0.01 to $14 \%$ ), Marinomonadacea (from 0 to $10 \%$ ), and Parvibaculaceae (from 0.2 to $13 \%$ ). This was mainly observed at incubation day 5. In the control treatment associated with the smaller picoplankton community $(0.7 \mu \mathrm{m})$, a greater relative abundance of Rhodobacteraceae (from 3.4 to $15 \%$ ) and Burkholderiaceae (from 0.2 to 34\%) were observed at incubation day 5 . After 15 days of incubation, a higher contribution of Saccarospirillaceae (from 0.3 to $43 \%$ ) and Nitrincolaceae (from 0.02 to $18 \%$ ) was observed. After PDE addition, a higher increase in the abundance of Rhodobacteraceae (from 3 to $45 \%$ ), Marinobacteraceae (from 0 to $35 \%$ ), and Xanthomonadaceae (from 0 to $17 \%$ ) was observed in the sequencing libraries between 5 and 15 days of incubation. Furthermore, a slight increase in Obscuribacterales, Arcobacteraceae, Cryomorphaceae, Parviculaceae, and Alteromonadacea was observed. The results from the main PERMANOVA test revealed significant differences between the incubation times (pseudo-F $=12.7, p=0.005$ ), as well as between the treatment with PDE addition and the control (pseudo- $\mathrm{F}=9.26, p=0.013$ ), and non-significant differences were 
observed between the different sizes of bacterioplankton assemblage (pseudo- $\mathrm{F}=4.05$, $p=0.09)$.
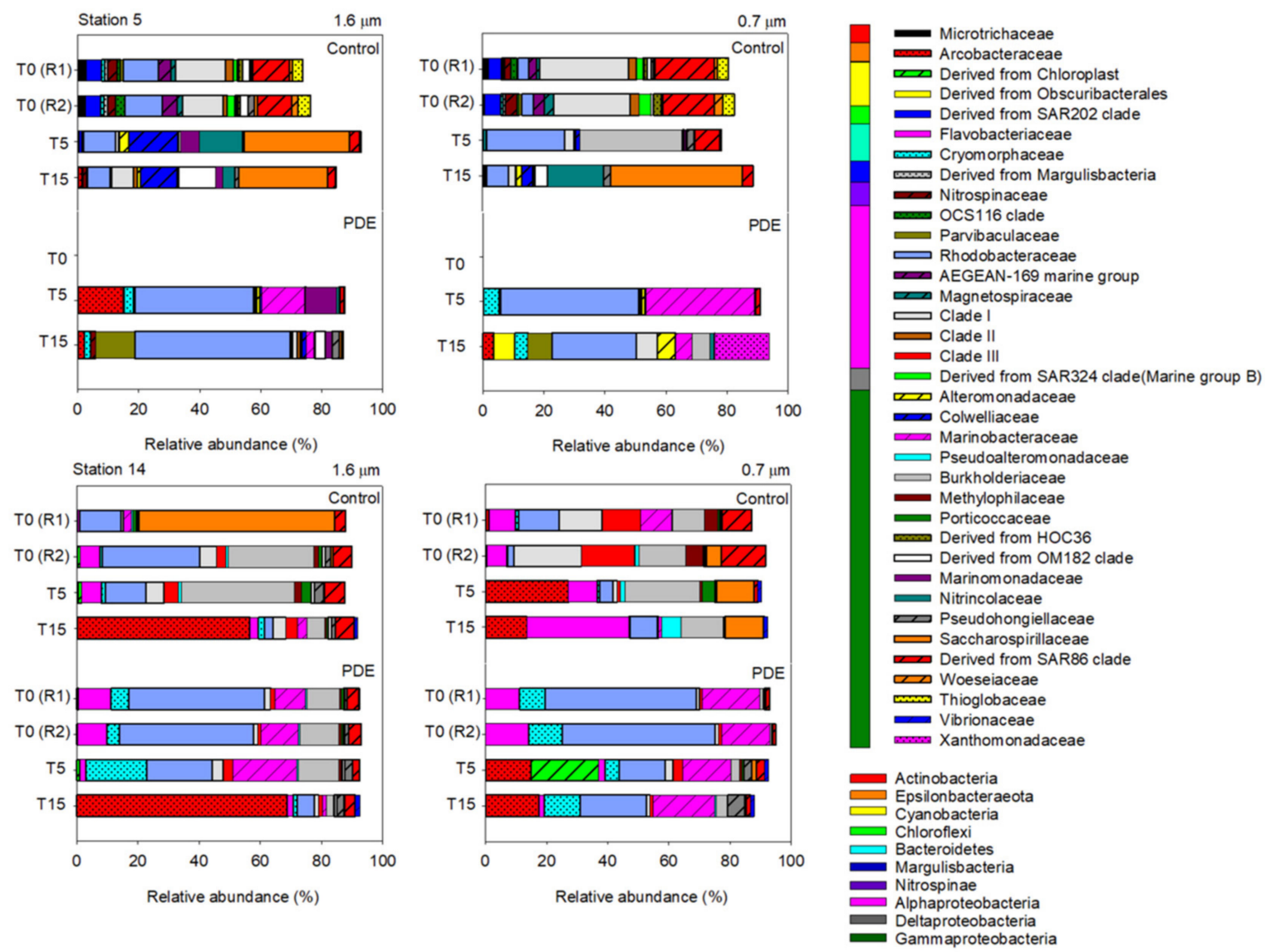

Figure 7. Contribution of active families through the incubation based on the SIMPER results. List of the OTUs explaining $50 \%$ of the dissimilarity observed during the experiment between treatments with PDE addition and control (without PDE) for each station. Upper panels correspond to marine station 5 and lower panels to estuarine station 14 .

At estuarine station 14 (Figure 7$)$, in the large size fraction treatment $(1.6 \mu \mathrm{m})$, the SIMPER analysis revealed an enrichment in the relative abundance of Arcobacteraceae towards the end of incubation (from 0.1 to $56 \%$ ). A notable reduction in Saccharospirillaceae relative abundance in the sequencing libraries was observed during the incubation (from $64 \%$ to $0.02 \%$ ); however, this family was not observed in both replicates at the initial time (T0). The dissimilarities between the incubation with PDE addition and the controls were explained by an increase in the relative abundance of Rhodobacteraceae at the initial time, followed by an increase of Cryomorphaceae (from 4 to 20\%) and Marinobacteraceae (from 10 to $20 \%$ ) at incubation day 5 . However, towards incubation day 15, an Arcobacteraceae enrichment from 0.02 to $69 \%$ was observed, along with a decrease in the relative abundance of Rhodobacteraceae, Cryomorphaceae, and Marinobacteraceae. The smaller size fraction $(0.7 \mu \mathrm{m})$ control treatment was characterized by an increase in the contribution of Arcobacteraceae (from 0.1 to $56 \%$ ), Flavobacteriaceae (0 to 6\%), and Burkholderiaceae (from 15 to 37\%) between the 5th and 15th day of incubation. Once the addition of PDE occurred, an increase in Rhodobacteraceae, Marinobacteraceae, and Cryomorphaceae was observed during all the times compared to the control treatments. The Arcobacterareae (from 0.02 to $69 \%$ ) abruptly increased at day 15, followed by an increase in Chloroplast and Pseudohongiellaceae at the incubation day 5 and towards the end of the incubation, respectively. However, the main PERMANOVA test showed non-significant differences between the treatment with PDE additions and the control (pseudo-F = 2.76, $p=0.066$ ) and 
between the different size classes (pseudo- $\mathrm{F}=2.18, p=0.1$ ), but significant differences were observed between the incubation times (pseudo- $\mathrm{F}=2.9, p=0.03$ ).

Furthermore, significant differences were observed between the different stations, (PERMANOVA; pseudo-F $=2.65, p=0.001$ ). Marine station 5 was characterized by a higher contribution of Alphaproteobacteria than estuarine station 14, which was characterized by the contribution of Gammaproteobacteria. The main dissimilarities between the stations were attributable to the contribution of Betaproteobacterales, Oceanospirillales, Campylobacterales, Rhodobacterales, and Alteromonadales, accounting for $30 \%$ of the dissimilarities between both stations.

A principal coordinate analysis (PCoA; Figure 8) considering the order taxa contribution and environmental parameters indicated that the marine station (Figure 8A), samples with PDE addition were associated with $\mathrm{Si}$ and $\delta^{13} \mathrm{C}$. At the estuarine station (Figure $8 \mathrm{~B}$ ), the samples were mostly grouped by incubation time rather than PDE addition; the initial time was associated with the Si concentrations.
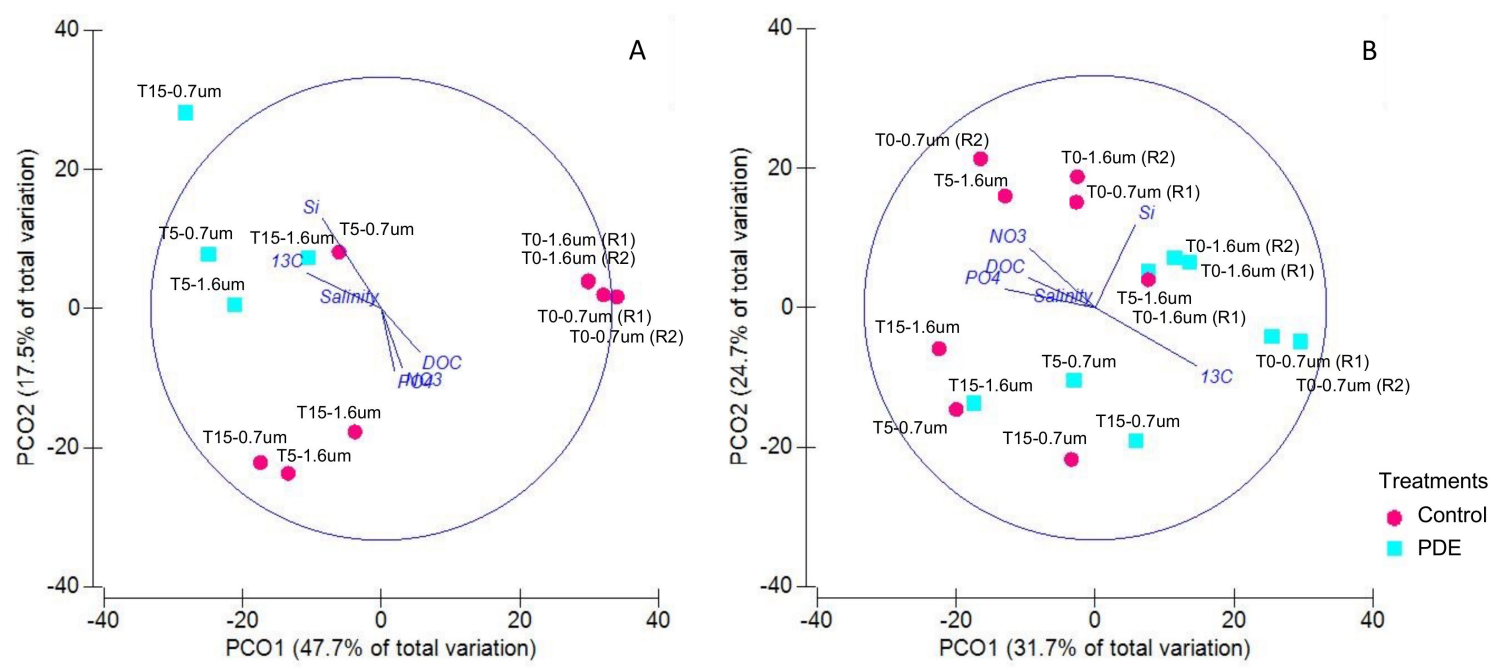

Figure 8. Principal component ordination of treatments with PDE and control based on Bray-Curtis similarity at order taxonomic level. (A) marine station 5 and (B) estuarine station 14. Vectors indicate the best environmental variables (normalized transformed) correlated with ordinations and vector lengths correspond to the correlation values.

\section{Discussion}

DOMs derived from phytoplankton reactivity and their use by fjord microbes were assessed by analyzing the response of bacterial communities in surface waters to PDE addition from contrasting environments with freshwater and marine influences along a land-ocean transect in Patagonian fjords. Our results indicated an increased bacterial abundance and changes in the community composition as immediate responses to PDE addition. The hydrography and nutrient concentrations registered in the water column during our study showed the influence of freshwater and marine conditions, as can be expected for this kind of ecosystem in Patagonian fjords during the austral spring [2]. The thicker and more extensive lower-salinity layer at the surface indicated that the fjord is subjected to freshwater discharge in spring from Steffen fjord, resulting in a strong land-ocean gradient, as has been reported by other authors $[2,6,8]$. The surface estuarine waters were characterized by lower nitrate and phosphate, but high silicate, compared to the marine waters. These characteristics in fjord waters play a key role in influencing the phytoplankton biomass and structure [2,34], as well as the microbial community structure and dynamics in Chilean fjords [15].

During our study, the active bacterial community composition suggests differences in the surface water between the marine and the estuarine types, with the dominance of Alphaproteobacteria and Gammaproteobacteria, respectively. These bacterial taxa were 
reported to be highly abundant in surface waters of high latitudes and fjord ecosystems in DNA survey studies [11-13,35]. Bacteroidetes, Alphapreoteobacteria, and Betaproteobacteria have been reported in freshwater and marine waters from Arctic fjords, and the differences between both microbial communities are mainly due to the presence of Epsilonproteobacteria in marine waters and of Gammaproteobacteria, Acidobacteria, Firmicutes, and Verrucomicrobia in estuarine waters [11,12,36]. In Chilean Patagonia and Antarctic waters at higher taxonomic levels, the dominance of Bacteroidetes and Alphaand Gammaproteobacteria members [15,35] has been observed. In our study, the Rhodobacteraceae, SAR11 clade I, and SAR86 families were characteristic of the marine waters, and in the estuarine freshwater, the presence of Rhodobacteraceae, Burkhoideriaceae, SAR86 clade, and SAR11 clades I and III were noted at the beginning of the incubation. Rhodobacteraceae and SAR11 clade I have been described as a representative family associated with estuarine freshwaters in Patagonian fjords $[15,35]$. Although the taxa of the active bacteria coincide with those of previous studies, bacterial community changes could be expected considering prefiltration and the time to set up the beginning of the experiments $(\sim 1 \mathrm{~h})$. Water collection and experimental incubations have been reported to trigger significant changes in the microbial community transcription associated, for example, with Alphaproteobacteria (SAR11-like) and Gammaproteobacteria (Collwelia from Alteromonadales) in the Eastern South Pacific [37].

\subsection{Potential Organic Matter Degradation by Different Small Microbial Size Fractions}

Phytoplankton and heterotrophic prokaryotes are major components of the microbial food web and interact continuously in very complex ways. The mainly fresh phytoplanktonderived DOM from phytoplankton blooms is a major energy source driving heterotrophic prokaryote and phytoplankton communities [20]. In accordance with this, the experimental incubations with PDE amendments in the marine and estuarine waters influenced DOM degradation, as evidenced by the reduction of $\sim 1.5 \mathrm{mg} \mathrm{L}^{-1}$ of DOC throughout the incubation, especially after 3 days of incubation in the estuarine water experiment. The DOC decrease was characterized by a major picoplankton bloom (Figure 5B), suggesting a net effect of DOC consumption by the heterotrophic bacterioplankton community. Moreover, the PDE amendments showed nitrate and phosphate accumulation at the end of the incubation in the marine experiment and during the entire incubation at the estuarine station (Supplementary Material Figure S1), indicating the presence of remineralization end-products. These results support previous studies suggesting the higher nitrification potential in surface waters and after organic-matter-addition experiments, such as the use of dissolved salmon food pellets [38].

The addition of PDE to natural bacterioplankton assemblages generated changes in abundance. Our results showed significant differences in bacterioplankton abundance between the treatment with PDE addition and controls only in the marine station. However, the addition of PDE did not show a higher increase in bacterial abundance compared to the control, and, in some cases, the control had greater abundances over time (e.g., Figure $4 \mathrm{~A}$, control $1.6 \mu \mathrm{m}$ ). In any case, the microbial response was more evident at the initial times, between 2 and 5 days of incubation. Furthermore, the presence of heterotrophic nanoflagellates (Supplementary Material Figure S2) can the explain picoplankton decrease by predation at the marine station. At the estuarine station, an intense bloom after 5 days of incubation in the treatment with PDE addition and inoculation with the small bacterioplankton size fraction was observed (Figure 4B). This bloom was also associated with a decrease in DOC concentration (Figure 3D). Many studies have shown the response of bacterioplankton to labile organic matter addition, as in our PDE treatments, as a driver of bacterioplankton growth, highlighting a rapid response (hours) in the form of bacterioplankton abundances after the addition of labile organic matter, independently of their origin [22,39]. 


\subsection{Active Bacterial Community Structure and Composition Responses during Surface Marine and Estuarine Water Incubations}

The bacterial community structure based on rarefying diversity evidenced differences between the control and PDE addition. In general, alpha diversity increased after the PDE additions compared to the initial time (particularly at the middle times). Proteobacteria, Bacteroidetes, and Epsilonbacteraeota phyla presented a greater contribution to our libraries and were the phyla showing the most significant differences during the experiments. The positive PDE taxon-specific active bacterial responses were attributed to Alphaproteobacteia, Gammaproteobacteria, and Epsilonbacteraeota, particularly Rhodobacteraceae, Marinobacteraceae (Marinobacter), Arcobacteraceae, and Cryomorphaceae regardless of the bacterioplankton community sizes $(1.6$ or $0.7 \mu \mathrm{m})$. The interpretation of the diversity and structure changes during the microcosm incubation is always a controversial issue due to a potential confinement effect. As in previous studies, an increase in Gammaproteobacteria taxa, probably related to the confinement $[38,40]$, occurred during our experiments. However, the bottle effect usually results in a decrease in total microbial diversity [41]; this was only detected at station 5 for the treatment incubated with the larger microbial size (Figure 5).

Recently, Kieft et al. [23] demonstrated that DOM composition has strong bottom-up control over the assembly of the active subset of the total community, which is generally composed of populations with specialized metabolic and ecophysiological traits, facilitating the efficient turnover of the highly heterogeneous pool of DOMs available throughout a phytoplankton bloom. In this sense, the increase in Gammaproteobacteria has been widely associated with phytoplankton bloom dynamics and with an increased concentration of DOMs in lower latitudes [42,43]. Teeling et al. [43] indicate that distinct populations of Bacteroidetes, Gammaproteobacteria, and Alphaproteobacteria are specialized to use algalderived organic matter, providing ecological niches in which specialized populations could bloom. In polar areas, changes in bacterial diversity have been observed after increases in chlorophyll-a concentrations during summer blooms, where Gammaproteobacteria, Alphaproteobacteria, and Bacteroidetes have the largest relative abundance and activity $[44,45]$. The Rhodobacteraceae family was found in all the treatments with PDE and controls; although this family was not abundant in the initial communities in this study, they become dominant members of fjords microbial communities during times of high levels of DOMs derived from phytoplankton inputs. The Rhodobacteraceae family has been detected in estuarine fresh waters in the Puyuhuapi fjord in Chilean Patagonia and is positively correlated with chlorophyll-a concentration $[15,35]$. Furthermore, this taxon is a specialized degrader of phytoplankton-derived compounds, such as DOM [46].

The Cryomorphaceae family (Bacteroidetes) showed lower abundances in the controls, and was even undetected in some cases, but increased their abundance significantly after PDE addition. This family has been positively correlated with phytoplankton community composition, especially with dinoflagellates, in Chilean Patagonia fjords [15]. Bacteroidetes are among the most abundant phyla in coastal areas [47]; they can degrade complex organic matter and are specialized in the degradation of biopolymers, such as proteins $[43,48]$. In this sense, the exacerbated input of nutrients that results from salmon culture and the increase in marine freshwater temperature and stratification promote shifts in phytoplankton community composition and blooming phenology [49], thereby modifying the microbial community structure and selecting the best-adapted taxa, even rare taxa, which was observed in Crypmorphacea family during our experiments. Furthermore, modifying the activity and community structure of microbes could significantly affect the cycling of organic matter in Patagonian fjords. Altogether, we conclude that the organic matter additions derived from phytoplankton exudates can significantly modify the structure of fjord microbial communities, favoring groups adapted to rapidly react to changes in their organic matter availability, which allows them to outcompete other abundant groups in the field during marine phytoplankton blooms. 
Supplementary Materials: The following are available online at https:/ / www.mdpi.com/article / 10.3390/d14030195/s1. Figure S1: Nutrient dynamic in response to PDE addition. Figure S2: Autotrophic and heterotrophic nanoflagellates during incubation experiments.

Author Contributions: H.E.G., C.F., R.G. and V.M. designed and funded the original research topic and experiments. R.G. carried out the experiments. V.V.-C. carried out the sample analysis. V.V.-C. and V.M. participated in the molecular analysis. V.V.-C. wrote the paper with equal contributions of all co-authors. All authors have read and agreed to the published version of the manuscript.

Funding: This research was funded by CONA Project C20F 14-31 “Rol de la materia orgánica en ciclos biogeoquímicos y trama trófica microbiana en un gradiente río-océano a lo largo de los fiordos Baker y Martínez", FONDECYT 1180954 and 1211977, FONDAP grants IDEAL 15150003, COPAS Sur-Austral ANID AFB170006, COPAS COASTAL ANID FB210021, and ANID FONDECYT postdoctorado 3210481. The work was developed in the framework of LIA MORFUN and LIA MAST.

Institutional Review Board Statement: Not applicable.

Informed Consent Statement: Not applicable.

Data Availability Statement: The libraries were deposited in the European Nucleotide Archive (ENA) under study accession PRJEB42326, with the following run access numbers: ERS5801012ERS5801039.

Acknowledgments: We thank the entire crew and all the scientists of the CIMAR 20-2014 oceanographic cruise, the CONA project C20F 14-31. We thank María Jesús Galvéz for RNA sample extractions. The authors dedicate this publication to Nelson Silva Sandoval (R.I.P), a pioneer in the study of chemical oceanography in Chile and in Chilean Patagonia.

Conflicts of Interest: The authors declare no conflict of interest.

\section{References}

1. González, H.; Calderón, M.; Castro, L.; Clement, A.; Cuevas, L.; Daneri, G.; Iriarte, J.; Lizárraga, L.; Martínez, R.; Menschel, E.; et al. Primary production and plankton dynamics in the Reloncaví Fjord and the Interior Sea of Chiloé, Northern Patagonia, Chile. Mar. Ecol. Prog. Ser. 2010, 402, 13-30. [CrossRef]

2. González, H.; Castro, L.; Daneri, G.; Iriarte, J.; Silva, N.; Tapia, F.; Teca, E.; Vargas, C. Land-ocean gradient in haline stratification and its effects on plankton dynamics and trophic carbon fluxes in Chilean Patagonian fjords (47-50 S). Prog. Oceanogr. 2013, 119, 32-47. [CrossRef]

3. González, H.; Castro, L.; Daneri, G.; Iriarte, J.; Silva, N.; Vargas, C.; Giesecke, R.; Sánchez, N. Seasonal plankton variability in Chilean Patagonia fjords: Carbon flow through the pelagic food web of Aysen Fjord and plankton dynamics in the Moraleda Channel basin. Cont. Shelf Res. 2011, 31, 225-243. [CrossRef]

4. Montero, P.M.; Tapia, F.; Iriarte, J.L.; Crawford, D.; Daneri, G. Diatom blooms and primary production in a channel ecosystem of central Patagonia. Lat. Am. J. Aquat. Res. 2017, 45, 999-1016. [CrossRef]

5. Dávila, P.M.; Figueroa, D.; Müller, E. Freshwater input into the coastal ocean and its relation with the salinity distribution off austral Chile (35-55 S). Cont. Shelf Res. 2002, 22, 521-534. [CrossRef]

6. Sievers, H.A.; Silva, N. 4.1 Masas de agua y circulación en los canales y fiordos australes. In Avances en el Conocimiento Oceanográfico de las Aguas Interiores Chilenas, Puerto Montt a cabo de Hornos; Comité Oceanográfico Nacional-Pontificia Universidad Católica de Valparaíso: Valparaíso, Chile, 2006; pp. 53-58.

7. Silva, N.; Vargas, C.A.; Prego, R. Land-ocean distribution of allochthonous organic matter in surface sediments of the Chiloé and Aysén interior seas (Chilean Northern Patagonia). Cont. Shelf Res. 2011, 31, 330-339. [CrossRef]

8. Vargas, C.A.; Martinez, R.A.; Martin, V.S.; Aguayo, M.; Silva, N.; Torres, R. Allochthonous subsidies of organic matter across a lake-river-fjord landscape in the Chilean Patagonia: Implications for marine zooplankton in inner fjord areas. Cont. Shelf Res. 2011, 31, 187-201. [CrossRef]

9. Iriarte, J.; León-Muñoz, J.; Marcé, R.; Clément, A.; Lara, C. Influence of seasonal freshwater streamflow regimes on phytoplankton blooms in a Patagonian fjord. New Zealand J. Mar. Freshw. Res. 2016, 51, 304-315. [CrossRef]

10. Montero, P.; Daneri, G.; González, H.E.; Iriarte, J.L.; Tapia, F.J.; Lizárraga, L.; Sanchez, N.; Pizarro, O. Seasonal variability of primary production in a fjord ecosystem of the Chilean Patagonia: Implications for the transfer of carbon within pelagic food webs. Cont. Shelf Res. 2011, 31, 202-215. [CrossRef]

11. Piquet, A.M.-T.; Scheepens, J.F.; Bolhuis, H.; Wiencke, C.; Buma, A.G.J. Variability of protistan and bacterial communities in two Arctic fjords (Spitsbergen). Polar Biol. 2010, 33, 1521-1536. [CrossRef]

12. Zeng, Y.-X.; Zhang, F.; He, J.-F.; Lee, S.H.; Qiao, Z.-Y.; Yu, Y.; Li, H.-R. Bacterioplankton community structure in the Arctic waters as revealed by pyrosequencing of $16 \mathrm{~S}$ rRNA genes. Antonie Leeuwenhoek 2013, 103, 1309-1319. [CrossRef] [PubMed] 
13. Gutiérrez, M.H.; Galand, P.E.; Moffat, C.; Pantoja, S. Melting glacier impacts community structure of Bacteria, Archaea and Fungi in a Chilean Patagonia fjord. Environ. Microbiol. 2015, 17, 3882-3897. [CrossRef]

14. Storesund, J.E.; Erga, S.R.; Ray, J.L.; Thingstad, T.F.; Sandaa, R.-A. Top-down and bottom-up control on bacterial diversity in a western Norwegian deep-silled fjord. FEMS Microbiol. Ecol. 2015, 91, fiv076. [CrossRef] [PubMed]

15. Gutiérrez, M.H.; Narváez, D.; Daneri, G.; Montero, P.; Pérez-Santos, I.; Pantoja, S. Linking Seasonal Reduction of Microbial Diversity to Increase in Winter Temperature of Waters of a Chilean Patagonia Fjord. Front. Mar. Sci. 2018, 5. [CrossRef]

16. Vargas, C.A.; Martínez, R.A.; Cuevas, L.A.; Pavez, M.A.; Cartes, C.; González, H.E.; Escribano, R.; Daneri, G. The relative importance of microbial and classical food webs in a highly productive coastal upwelling area. Limnol. Oceanogr. 2007, 52, 1495-1510. [CrossRef]

17. Blanchet, M. Metabolic and Composition Changes in Marine Bacterial Community Exposed to Variable Natural Organic Matter Bioreactivity. Ph.D. Thesis, Université Pierre et Marie Curie, Paris, France, 2015.

18. Jenkinson, D.S.; Fox, R.H.; Rayner, J.H. Interactions between fertilizer nitrogen and soil nitrogen-the so-called 'priming' effect. Eur. J. Soil Sci. 1985, 36, 425-444. [CrossRef]

19. McCarren, J.; Becker, J.W.; Repeta, D.J.; Shi, Y.; Young, C.R.; Malmstrom, R.; Chisholm, S.; DeLong, E.F. Microbial community transcriptomes reveal microbes and metabolic pathways associated with dissolved organic matter turnover in the sea. Proc. Natl. Acad. Sci. USA 2010, 107, 16420-16427. [CrossRef]

20. Sarmento, H.; Gasol, J.M. Use of phytoplankton-derived dissolved organic carbon by different types of bacterioplankton. Environ. Microbiol. 2012, 14, 2348-2360. [CrossRef] [PubMed]

21. Steen, A.D.; Quigley, L.N.M.; Buchan, A. Evidence for the Priming Effect in a Planktonic Estuarine Microbial Community. Front. Mar. Sci. 2016, 3, 6. [CrossRef]

22. Landa, M.; Cottrell, M.; Kirchman, D.; Blain, S.; Obernosterer, I. Changes in bacterial diversity in response to dissolved organic matter supply in a continuous culture experiment. Aquat. Microb. Ecol. 2013, 69, 157-168. [CrossRef]

23. Kieft, B.; Li, Z.; Bryson, S.; Hettich, R.L.; Pan, C.; Mayali, X.; Mueller, R.S. Phytoplankton exudates and lysates support distinct microbial consortia with specialized metabolic and ecophysiological traits. Proc. Natl. Acad. Sci. USA 2021, 118, e2101178118. [CrossRef] [PubMed]

24. Blanchet, M.; Pringault, O.; Panagiotopoulos, C.; Lefèvre, D.; Charrière, B.; Ghiglione, J.-F.; Fernandez, C.; Aparicio, F.L.; Marrasé, C.; Catala, P.; et al. When riverine dissolved organic matter (DOM) meets labile DOM in coastal waters: Changes in bacterial community activity and composition. Aquat. Sci. 2016, 79, 27-43. [CrossRef]

25. Carlson, C.A.; Hansell, D.A. DOM Sources, Sinks, Reactivity, and Budgets. In Biogeochemistry of Marine Dissolved Organic Matter; Elsevier: Amsterdam, The Netherlands, 2015; pp. 65-126. [CrossRef]

26. Grasshoff, K.; Ehrhardt, M.; Kremling, K.; Anderson, L.G. (Eds.) Methods of Seawater Analysis, 3rd ed.; completely rev. and extended ed.; Wiley-VCH: Weinheim, Germany; New York, NY, USA, 1999.

27. Parson, T.; Maita, Y.; Lalli, C. A Manual of Chemical and Biological Methods for Seawater Samples Analysis; Pergamon Press: Oxford, UK, 1984; p. 173.

28. Cauwet, G. HTCO method for dissolved organic carbon analysis in seawater: Influence of catalyst on blank estimation. Mar. Chem. 1994, 47, 55-64. [CrossRef]

29. Marie, D.; Partensky, F.; Jacquet, S.; Vaulot, D. Enumeration and Cell Cycle Analysis of Natural Populations of Marine Picoplankton by Flow Cytometry Using the Nucleic Acid Stain SYBR Green I. Appl. Environ. Microbiol. 1997, 63, 186-193. [CrossRef]

30. Villafañe, V.; Reid, F. Métodos de Microscopía para la Cunatificación de Fitoplankton. In Manual de Métodos Ecológicos; Alveal, K., Ferrario, M., Oliviera, E., Sar, E., Eds.; Concepción: Editorial Aníbal Pinto; Universidad de Concepción: Concepción, Chile, 1995; pp. 169-185.

31. Valdés, V.P.; Fernandez, C.; Molina, V.; Escribano, R.; Joux, F. Dissolved Compounds Excreted by Copepods Reshape the Active Marine Bacterioplankton Community Composition. Front. Mar. Sci. 2017, 4, 343. [CrossRef]

32. Schloss, P.D.; Westcott, S.L.; Ryabin, T.; Hall, J.R.; Hartmann, M.; Hollister, E.B.; Lesniewski, R.A.; Oakley, B.B.; Parks, D.H.; Robinson, C.J.; et al. Introducing mothur: Open-Source, Platform-Independent, Community-Supported Software for Describing and Comparing Microbial Communities. Appl. Environ. Microbiol. 2009, 75, 7537-7541. [CrossRef]

33. Edgar, R.C.; Haas, B.J.; Clemente, J.C.; Quince, C.; Knight, R. UCHIME improves sensitivity and speed of chimera detection. Bioinformatics 2011, 27, 2194-2200. [CrossRef]

34. Quast, C.; Pruesse, E.; Yilmaz, P.; Gerken, J.; Schweer, T.; Yarza, P.; Peplies, J.; Glöckner, F.O. The SILVA ribosomal RNA gene database project: Improved data processing and web-based tools. Nucleic Acids Res. 2013, 41, D590-D596. [CrossRef]

35. Vargas, C.A.; Cuevas, L.A.; Silva, N.; González, H.E.; De Pol-Holz, R.; Narváez, D.A. Influence of Glacier Melting and River Discharges on the Nutrient Distribution and DIC Recycling in the Southern Chilean Patagonia. J. Geophys. Res. Biogeosci. 2018, 123, 256-270. [CrossRef]

36. Tamayo-Leiva, J.; Cifuentes-Anticevic, J.; Aparicio-Rizzo, P.; Arroyo, J.I.; Masotti, I.; Díez, B. Influence of Estuarine Water on the Microbial Community Structure of Patagonian Fjords. Front. Mar. Sci. 2021, 8, 948. [CrossRef]

37. Piquet, A.M.-T.; Maat, D.S.; Confuriusguns, V.; Sintes, E.; Herndl, G.J.; Van De Poll, W.H.; Wiencke, C.; Buma, A.G.J.; Bolhuis, H. Springtime dynamics, productivity and activity of prokaryotes in two Arctic fjords. Polar Biol. 2015, 39, 1749-1763. [CrossRef] 
38. Stewart, F.J.; Dalsgaard, T.; Young, C.R.; Thamdrup, B.; Revsbech, N.P.; Ulloa, O.; Canfield, D.; Delong, E.F. Experimental Incubations Elicit Profound Changes in Community Transcription in OMZ Bacterioplankton. PLoS ONE 2012, 7, e37118. [CrossRef] [PubMed]

39. Fernandez, C.; Rain-Franco, A.; Rojas, C.; Molina, V. Ammonium release via dissolution and biological mineralization of food pellets used in salmon farming. Aquac. Res. 2019, 51, 779-793. [CrossRef]

40. Dinasquet, J.; Kragh, T.; Schrøter, M.-L.; Søndergaard, M.; Riemann, L. Functional and compositional succession of bacterioplankton in response to a gradient in bioavailable dissolved organic carbon. Environ. Microbiol. 2013, 15, 2616-2628. [CrossRef] [PubMed]

41. Massana, R.; Pedrós-Alió, C.; Casamayor, E.O.; Gasol, J.M. Changes in marine bacterioplankton phylogenetic composition during incubations designed to measure biogeochemically significant parameters. Limnol. Oceanogr. 2001, 46, 1181-1188. [CrossRef]

42. Valdés, V.; Fernandez, C.; Molina, V.; Escribano, R. Nitrogen excretion by copepods and its effect on ammonia-oxidizing communities from a coastal upwelling zone. Limnol. Oceanogr. 2017, 63, 278-294. [CrossRef]

43. Tada, Y.; Taniguchi, A.; Nagao, I.; Miki, T.; Uematsu, M.; Tsuda, A.; Hamasaki, K. Differing Growth Responses of Major Phylogenetic Groups of Marine Bacteria to Natural Phytoplankton Blooms in the Western North Pacific Ocean. Appl. Environ. Microbiol. 2011, 77, 4055-4065. [CrossRef]

44. Teeling, H.; Fuchs, B.M.; Becher, D.; Klockow, C.; Gardebrecht, A.; Bennke, C.M.; Kassabgy, M.; Huang, S.; Mann, A.J.; Waldmann, J.; et al. Substrate-Controlled Succession of Marine Bacterioplankton Populations Induced by a Phytoplankton Bloom. Science 2012, 336, 608-611. [CrossRef]

45. Alcaman, M.E.; Farias, L.; Verdugo, J.; Alarcón-Schumacher; Díez, B. Microbial Activity during a Coastal Phytoplankton Bloom on the Western Antarctic Peninsula in Late Summer. FEMS Microbiol. Lett. 2018, 365, fny090. [CrossRef]

46. Fuentes, S.; Arroyo, J.I.; Rodríguez-Marconi, S.; Masotti, I.; Alarcon-Schumacher, T.; Polz, M.F.; Trefault, N.; De La Iglesia, R.; Díez, B. Summer phyto- and bacterioplankton communities during low and high productivity scenarios in the Western Antarctic Peninsula. Polar Biol. 2018, 42, 159-169. [CrossRef]

47. Buchan, A.; LeCleir, G.R.; Gulvik, C.A.; Gonzalez, J.M. Master recyclers: Features and functions of bacteria associated with phytoplankton blooms. Nat. Rev. Microbiol. 2014, 12, 686-698. [CrossRef] [PubMed]

48. Alonso-Sáez, L.; Gasol, J.M. Seasonal Variations in the Contributions of Different Bacterial Groups to the Uptake of Low-MolecularWeight Compounds in Northwestern Mediterranean Coastal Waters. Appl. Environ. Microbiol. 2007, 73, 3528-3535. [CrossRef] [PubMed]

49. Pinhassi, J.; Azam, F.; Hemphälä, J.; Long, R.A.; Martinez, J.; Zweifel, U.L.; Hagström, A.A. Coupling between Bacterioplankton Species Composition, Population Dynamics, and Organic Matter Degradation. Aquat. Microb. 1999, 17, 13. [CrossRef] 